\title{
O ESTUDO DA LÍNGUA E SUA RELAÇÃO COM A ESCRITA: PROJEÇÓES TEÓRICAS DE ÉMILE BENVENISTE
}

\section{THE STUDY OF LANGUAGE AND ITS RELATIONSHIP WITH WRITING: THEORETICAL PROJECTIONS OF ÉMILE BENVENISTE}

\author{
Aline Wieczikovski Rocha \\ Universidade de Passo Fundo, UPF, Passo Fundo, RS, Brasil \\ Claudia Stumpf Toldo \\ Universidade de Passo Fundo, UPF, Passo Fundo, RS, Brasil
}

Resumo: Este estudo objetiva apresentarmos algumas das consideraçóes teóricas do linguista Émile Benveniste, na obra Últimas aulas no Collège de France 1968-1969 (2014), a respeito do tema da escrita, especialmente os argumentos que desenvolve para refletir acerca da relação semiológica entre o sistema da língua e o sistema da escrita. Sob esse viés, trazemos para este debate a análise de Benveniste sobre a escrita e sua capacidade de significar a língua. Para tanto, observamos a produção intelectual de Benveniste, vinculada às Últimas aulas, estabelecer um passo teórico (re)configurador da análise linguística, já que o caminho é orientado sobre estes dois determinantes: o da propriedade semiótica, que reveste o sistema de signos da língua, e o da propriedade semântica, que reveste a produção do discurso; e dimensionador da própria língua, dado o seu caráter de interpretância.

Palavras-chave: língua; escrita; relação semiológica.

Abstract: This study aims to present some of the theoretical considerations of liinguist Émile Benveniste, in the book Last Lecturs: Collége de France 1968 and 1969 (2014), regarding the subject of writing, specially the arguments he develops to reflect on the semiological relationship between the language system and the writing system. Under this bias, we bring to this debate Benveniste's analysis on writing and its capacity of meaning the language. Therefore, we observe the intelectual production of Benveniste, linked to the Last lecturs, to establish a theoretical step re-configurator of linguistic analysis, since the path is oriented on the these two determinants: the semiotic property, which coats the system of signs of the language, and the semantic property, wich coats the production of discourse; and dimensioner of the language itself, given its character of interpretance.

Key words: language; written/writing; semiological relationship. 


\section{Consideraçóes iniciais: o lugar teórico das liçóes benvenistianas}

Últimas aulas no Collège de France 1968-1969 (2014), doravante UA, traz à luz as ideias do linguista Émile Benveniste sobre a semiologia e a escrita. Situado no contexto efervescente do movimento estruturalista, o linguista, em suas aulas, assegura um novo tom, tanto para o caráter teórico de suas reflexóes, quanto para o conteúdo que decide expor. Mostrandose um "herdeiro confirmado de Saussure e fiel ao termo semiologia [...] compartilha com seus contemporâneos semioticistas a ambição de descrever a globalidade do mundo social em termos de sistemas de signos" (NORMAND, 2009a, p. 160). É dessa maneira que a semiologia, que tanto empenho desencadeou nas frentes de pensamento do estruturalismo, recebe o trato intelectual de Benveniste nas Últimas aulas. Vale lembrar que esse nobre linguista presidiu em 1969 a Associação Internacional de Semiótica, fato que corrobora sua inserção nessas bases de discussão.

Nesse enquadre, acessar a leitura dessa obra benvenistiana significa ingressar em um cenário de proposiçóes centrado nestes pontos: o primeiro trata da abordagem sobre a compreensão do que circunscreve a linguística geral e a funçáo do linguista face ao objeto; o segundo marca a materialidade do fundamento semiológico pelo olhar de Benveniste; e o terceiro concerne à análise do princípio de relaçóes entre o sistema da língua e o sistema da escrita.

Dessa forma, o estudo proposto na exposição de Benveniste reflete, conforme a percepção de Normand (1996, p. 137), sua "vontade de continuar Saussure, ultrapassando-o", pois o movimento teórico de Benveniste parte ora da certificaçáo, ora do confronto com o que se projeta no Curso saussuriano, daí a justificativa de traçar a perspectiva de que "Saussure deve ser ultrapassado pelo desenvolvimento do que é no Curso um elemento central mas insuficientemente elaborado, a questão da significação" (NORMAND, 1996, p. 137). É, pois, munido dessa presença de uma língua informada de significação, que compreendemos os passos iniciais do alargamento da visão projetada por Benveniste ao anunciar que "compete-nos tentar ir além do ponto a que Saussure chegou na análise da língua como sistema significante" (BENVENISTE, 2006, p. 224). Desenvolver, portanto, as questóes que envolvem a semiologia saussuriana, enquanto ciência piloto, oportuniza a Benveniste prolongar os princípios saussurianos e ultrapassá-los pela análise do funcionamento da língua, isto é, pelas dimensôes de forma e sentido. 
Para acompanhar a linha racional das aulas de Benveniste, devemos considerar, também, a conjuntura projetada em outras liçóes, aquelas formalizadas em seus Problemas de linguistica gerall. Isso porque o revestimento semiótico e semântico da língua é basilar da apresentação de uma semiologia distinta da que Saussure enunciou, a proposta de Benveniste não está fundada "exclusivamente sobre a noção de signo, tal como em Saussure, mas sobre o discurso e, principalmente, sobre o aspecto próprio da língua de ser interpretante de si e dos outros sistemas semiológicos" (FLORES, 2013, p. 158). Assim, se, na apresentação saussuriana, a semiologia é sígnica, na benvenistiana, a semiologia é a da lingua, porque é discursiva, porque sua interpretância parte do engendramento dos domínios do semiótico e do semântico da língua. O ultrapassar Saussure, como propóe Normand (1996), não se constitui pelo gesto de negação do fazer saussuriano, diremos que se constitui muito mais pelo que Benveniste herda de Saussure e consegue projetar sobre ele e sobre sua - inicial - percepção da língua enquanto sistema. Isso inclui a elaboração de uma ciência das relaçôes (BENVENISTE I, 2005, p. 18), e dessa ciência fazer nascer um novo domínio, o da semiologia da língua.

Surge, dessa maneira, a tarefa central deste estudo, inscrita no objetivo de entendermos como Benveniste insere o tema da escrita no debate de uma relação semiológica com a língua. Para isso, percorreremos, primeiro, as liçôes sobre a semiologia somadas ao conteúdo de Problemas de Linguística Geral; segundo, as liçôes sobre a língua e a escrita, que representam o novo capítulo dos pressupostos teóricos do fazer linguístico benvenistiano. Passemos, então, a esse empreendimento.

\section{A língua e o seu papel de interpretante semiológico}

Nas Últimas aulas no Collège de France $1968-1969$ (2014), o linguista Émile Benveniste conserva uma postura delimitadora da visão que prospecta, pois, habilmente, propóe falar sobre, ao mesmo tempo em que define, a sua compreensão de uma linguística geral, ou seja, para ele, é importante esclarecer o empenho sobre "a linguística que se interroga sobre si mesma, sobre sua definição, sobre seu objeto, sobre seu estatuto e sobre seus métodos" (BENVENISTE, 2014, p. 90). Trata-se de produzir "uma interrogação incessante, que se desenvolve, que se renova na medida em

${ }^{1}$ Os dois tomos de Problemas de linguística geral de Émile Benveniste serão referidos, aqui, com sistema de sigla (PLG) e indicaçáo do volume (I ou II). 
que a experiência do linguista se aprofunda e seu olhar se amplia. Falar de 'linguística' é falar da língua" (BENVENISTE, 2014, p. 90). No âmbito dessa questão, a experiência do linguista é constitutiva do saber dizer "onde se encontra a língua" e "como falar dela". (BENVENISTE, 2014, p. 90). Essa abordagem de Benveniste encaminha e recupera, como já observamos, a propriedade elementar da natureza significante da língua, que orienta todo seu discurso, a saber: "será um discurso sobre a característica que colocamos em primeiro plano: a língua significa" (BENVENISTE, 2014, p. 90, grifo do autor).

A partir disso, o leitor do curso de Benveniste depara-se com as notas que encaminham a construção pedagógica e organizacional da trajetória das intenções desse linguista para introduzir aos seus ouvintes uma linguística que verse o plano da significância, "a ideia de que os signos podem formar conjuntos coerentes, sistemas de signos, e que eles propiciam o aparecimento de uma nova ciência, a ciência dos signos, a semiologia" (BENVENISTE, 2014, p. 91, grifos do autor). O salto teórico do linguista começa a se delinear quando se lança ao alcance da compreensão de outros sistemas em relação ao sistema da língua. Nessa análise, Benveniste designa que "a língua é não apenas feita de signos, mas também produtora de signos, que o sistema que a compóe engendra, ele próprio, novos sistemas, dos quais a língua é o interpretante" (BENVENISTE, 2014, p. 101). Isso a coloca num lugar diferenciado ao olharmos para os sistemas sígnicos. A língua é um sistema único e diferenciado em relação aos outros. Sem dúvida, o mais importante. No exame dessa proposição, impressiona a robustez da língua. Em sua dinâmica processual, a língua é tecida em signos e fabricadora de signos, o sistema dessa língua engendra a existência de novos sistemas; e, por fim, a língua interpreta, dá sentido a esses sistemas. Essa engrenagem faz da língua um sistema de excelência ao passo que amplia e impulsiona a visão de sua essência.

Dado esse passo, Benveniste estabelece as condições viabilizadoras para pensar na língua revestida da competência interpretante e, com isso, pode investir no objeto da semiologia, fundamentado nas "RELAÇÓES entre estes sistemas" (BENVENISTE, 2006, p. 51, grifos do autor) de signos. A explanação das liçóes de Benveniste marca, dessa maneira, "uma nova relação, que Saussure não mencionou, nem talvez tenha visto: a relação de interpretação" (BENVENISTE, 2014, p. 109, grifos do autor). Logo, a espessura dessa proposiçáo benvenistiana reencaminha o funcionamento do sistema da língua enquanto matriz semiótica. 
Nesse modo de ver, Benveniste salienta que "os sistemas semióticos diferentes da língua não se bastam a eles mesmos e todos têm necessidade de verbalização; por essa razão primordial, apenas é significante o que é denominado pela linguagem" (BENVENISTE, 2014, p. 109). Ofertada a notoriedade da língua, Benveniste traça um rumo distinto do que se propóe em termos de semiologia, pois "a língua como sistema de expressão [...] é o interpretante de todas as instituiçôes e de toda a cultura" (BENVENISTE, 2014, p. 117). Nesses termos, Benveniste certifica que "toda semiologia de um sistema náo linguístico deve pedir emprestada a interpretação da língua, não pode existir senão pela e na semiologia da língua" (BENVENISTE, 2006, p. 61). Dizendo isso, o linguista reitera a condição da língua de interpretante de todos os sistemas, razáo pela qual a semiologia, segundo sua perspectiva, deve ser a de uma semiologia da língua.

Vale destacar, ainda, os elementos que identificam a singularidade da língua em matéria de sistema. Benveniste pontua estes:

\footnotetext{
$1^{\circ}$ ela se manifesta pela enunciação, que contém referência a uma situação dada; falar, é sempre falar-de;

$2^{\circ}$ ela consiste formalmente de unidades distintas, sendo que cada uma é um signo;

$3^{\circ}$ ela é produzida e recebida nos mesmos valores de referência por todos os membros de uma comunidade;

$4^{\circ}$ ela é a única atualização da comunicação intersubjetiva (BENVENISTE, 2006, p. 63).
}

Para expressar a ideia de sistema autointerpretante, Benveniste exemplifica a relação entre dois sistemas: o da língua e o da sociedade. Embora se estabeleçam como dois sistemas, língua e sociedade não apresentam "correlação estrutural". Por isso, "a relação só pode ser semiológica, isto é uma relação de interpretante com interpretado, que exclui toda relação genética. A língua contém a sociedade" (BENVENISTE, 2014, p. 111). Dizer que a lingua contém a sociedade é dizer que "somente é social aquilo que a língua denomina” (BENVENISTE, 2014, p. 112). É nesse sentido que a língua se estabelece com a propriedade de sistema interpretante.

O ponto de vista de Benveniste esclarece que "a principal diferença entre a língua e os 'sistemas semióticos' é que nenhum sistema semiótico é capaz de se tomar, ele próprio, como objeto nem de se descrever em seus termos" (BENVENISTE, 2014, p. 120, grifos do autor). Essa evidência norteará os desdobramentos da relaçáo de interpretância entre o sistema da língua e o sistema da escrita, a questão é, entendermos adiante, a partir das 
aulas de Benveniste, como, em seu raciocínio linguístico, a língua categoriza e interpreta ela mesma.

Por ora, reteremos, desse conjunto de noçóes, que o ponto teórico fundamental é o de que a língua "está investida de propriedades semânticas [...], ela funciona como uma máquina de produzir sentido" (BENVENISTE, 2006, p. 99). A propriedade estrutural da língua permite sua propriedade funcional da produção do sentido o qual é convocado à relaçáo de interpretância da língua. $\mathrm{O}$ valor da língua como máquina de produzir sentido insere-se no contexto do que o linguista propóe ser as "duas maneiras de ser língua, no sentido e na forma" (BENVENISTE, 2006, p. 229), isto é, "a língua como semiótica [...] língua como semântica" (BENVENISTE,2006, p. 229, grifos do autor). Por isso, ser reconhecido é uma incumbência destinada ao semiótico/signo e ser compreendido ao semântico/discurso. Este, na acepção benvenistiana, é o privilégio da língua, "comportar simultaneamente a significância dos signos e a significância da enunciação" (BENVENISTE, 2006, p. 66). Para o linguista, "daí provém seu poder maior, o de criar um segundo nível de enunciação, em que se torna possível sustentar propósitos significantes sobre a significância" (BENVENISTE, 2006, p. 66). Eis a essência interpretante da língua.

Isso posto, tomemos, na seção seguinte, os desdobramentos explicativos de Benveniste para esse fundamento da interpretância.

\section{O fundamento da autossemiotizaçáo da língua}

A análise da relação de interpretação entre o sistema da língua e o sistema da escrita é a oportunidade para o que Benveniste propóe ser a semiotização da língua. A análise de Benveniste desloca-se ao exame da função semiótica da escrita, anunciado na constatação de que há um processo de autossemiotização da língua. Seguindo as motivaçôes de Benveniste, a escrita é um "instrumento que permite à lingua semiotizar a si mesma" (BENVENISTE, 2014, p. 155, grifo do autor). A escrita figura, nesse sentido, como o instrumento da autossemiotização da língua, uma vez que detém propriedades muito particulares, como a metalinguística.

Retomando o princípio do poder significante da língua, Benveniste demonstra como a língua "pode e pode sozinha - dar a um objeto ou a um processo qualquer o poder de representar" (BENVENISTE, 2014, p. 157, grifo do autor). Entáo, a língua pode dar ao processo da escrita o poder de 
representar, de significar. Assim, se "a língua opera uma redução sobre si mesma" (BENVENISTE, 2014, p. 157), cabe à escrita ser o instrumento dessa representação semiótica. A noção de representação, posta dessa maneira, é a de uma relação semiológica,

uma relação de interpretação entre sistemas, o sistema da língua e o sistema da escrita.

As liçôes de Benveniste protagonizando a escrita, com o objetivo de "estudar a língua, depois sua relaçáo com a escrita, para ver como uma e outra significavam" (BENVENISTE, 2014, p. 173, grifos do autor), comportam formulaçốes singulares de seu pensamento, bem como o delinear de uma visão teórica nova para reconstruir a escrita como objeto de análise e enunciar que o resultado de sua investigação é o de que "a língua e a escrita significam exatamente da mesma maneira” (BENVENISTE, 2014, p. 173). A novidade do programa das liçóes de Benveniste remove a escrita do lugar comum de representaçáo subordinada da língua, demonstrando que ela é a possibilidade de refletirmos sobre a semiotização da língua, ensinando-nos a construir, linguisticamente, o lugar da própria significação.

Com essa proposição, Benveniste alça a escrita a um status extremamente singular. Esse linguista convoca a excelência da língua como sistema significante na prova da escrita, ela é a face semiotizável da língua, a memória semiótica do corpo da língua, a materialização metalinguística.

Desse modo, falar de escrita, a partir de um ponto de vista linguístico, implica ultrapassar a presença de uma escrita literalizada, conformada. É preciso fundar o semiótico da língua, realizar graficamente o semiótico, para passar a sua dimensão semântica, pois o encontro entre a língua e a escrita se dá nesse domínio de proposiçôes. Nisso, Benveniste faz ver a dupla significância da língua e tal condição faz da língua um organismo significante. A exposição de Benveniste torna-se distinta, porque não consiste em escamotear a escrita do estudo linguístico, ele trabalha esse sistema a partir da significância da escrita, ou seja, a capacidade desse sistema de operar a significância da própria língua. Passemos à próxima seção para melhor entendermos a questáo.

\section{Os movimentos de significância da língua pela escrita}

Ao apresentar como objeto e problema de linguística geral a língua e a escrita, Benveniste observa dois princípios: 1) a lingua semiotiza tudo; 
2) a língua semiotiza a si mesma. A visão desse linguista diz que esses dois princípios pertencem à elaboração da escrita, porque "a língua opera uma redução sobre si mesma” (BENVENISTE, 2014, p. 157).

Para o linguista, a denominação dessa operação está reservada ao processo linguístico, ou seja, compreender "como uma língua nomeia o ato que lhe dá expressão escrita” (BENVENISTE, 2014, p. 167). Trata-se, então, de poder "distinguir entre a designação e a significação" (BENVENISTE, 2014, p. 167). Sobre a designação, os apontamentos de Benveniste encaminham à compreensão do modo como se designam os atos de ler e de escrever: "Há uma ordem imposta pela experiência e pela pedagogia: primeiro ler, depois escrever. Mas essa não é a ordem da invençâo" (BENVENISTE, 2014, p. 167). Para preencher o sentido da escrita enquanto operação, é necessário conceber, no entanto, que "É o escrever que foi o ato fundador" (BENVENISTE, 2014, p. 167). Assim, na inferência de Benveniste, a operaçáo da escrita funda o ato da leitura, delineando nova reflexão destinada à questão da significação.

O exame de relaçôes entre o sistema da escrita e o sistema da língua está argumentado nesta realização do processo de autossemiotização da língua, uma vez que imprime, pois, as formas da língua. Além disso, a escrita se constitui também por este "princípio fundamental: a escrita é uma forma secundária da fala" (BENVENISTE, 2014, p. 177, grifos do autor). Entendemos, assim, que essa manifestação como uma forma secundária da fala se deve ao fato de a escrita comportar "as duas propriedades, semiótica e semântica, características do discurso, e apenas do discurso, ou só da expressão linguística, em face dos outros sistemas semiológicos" (BENVENISTE, 2014, p. 178). Isso se sustenta no adiantado da explicação de Benveniste que reconhece "'essa linguagem visível' que é a escrita" como "realização de uma forma secundária do discurso" (BENVENISTE, 2014, p. 179, grifos nossos). Então, se a língua remete à língua-discurso de igual modo à fala, a escrita, em sua forma secundária, também deve remeter ao discurso.

Nessas formulaçóes de Benveniste, é perceptível que sua maneira de conceber o estudo da escrita foge às práticas de fazê-la proceder da oralidade. É importante lembrar que, à época de suas aulas, a reflexão linguística caracteristicamente concebia a escrita como a clausura da fala, a impossibilidade da linguagem viva. Essa assimetria da fala e da escrita é, como se pode constatar no percurso da leitura das Últimas aulas, gradativamente reinterpretada por Benveniste, porque dar manutenção a 
oposiçóes como essa inviabiliza o próprio fazer da linguística, pois, segundo o linguista, seria difícil a "análise da linguagem falada se não se dispusesse dessa 'linguagem visível”” (BENVENISTE, 2014, p. 179). Benveniste apoia essa possibilidade da linguística, apontando que "Só essa realização de uma forma secundária do discurso permitiu tomar consciência do discurso em seus elementos formais e analisar todos os seus aspectos" (BENVENISTE, 2014, p. 179). A escrita estabelece relação com a língua na medida em que permite ver a língua, "é, portanto, um revezamento (relais) da fala, é a própria fala fixada em um sistema secundário de signos. Mas ainda que secundário, esse sistema continua sendo o da própria fala, sempre apto a se tornar fala de novo" (BENVENISTE, 2014, p. 179, grifo do autor). Mais uma das razóes linguísticas benvenistianas para que língua e escrita não sejam concebidas em separado.

Dessa maneira, o ponto de vista benvenistiano destaca que, "a partir do momento em que se coloca a escrita no prolongamento da fala e sempre como uma forma de fala, parece que a escrita é não um signo, mas um revezamento da fala" (BENVENISTE, 2014, p. 181). Isso significa transformarmos a escrita em "um dispositivo que retoma e retransmite o conjunto dos signos recebidos". (BENVENISTE, 2014, p. 181). Embora Benveniste não discorra detalhadamente por que a escrita não é um signo ou o que podemos propor nesse revezamento da fala, algumas proposiçôes convergentes com a linha teórica de Benveniste permitem-nos o ensaio de uma apresentação.

As percepçôes de Coquet (2016) sobre tomar a escrita como signo ou como traço demonstram uma particularidade que nos parece produtiva na projeção do universo teórico benvenistiano. Segundo a apresentação de Coquet (2016, p. 66, tradução nossa), "Em fenomenologia da linguagem, a escrita realizou-se por um 'traço', em filosofia da linguagem, por um 'signo'”. Isso equivale a dizer que, "de um lado, o traço deixado pela enunciação oral (a fala) ou escrita; o signo como elemento de um sistema, de outro" (COQUET, 2016, p. 66, tradução nossa). Devemos, desse modo, considerar que "nós temos do lado da fenomenologia da linguagem: traço, enunciação, o dizer, e do lado da filosofia da linguagem, signo, enunciado, o dito" (COQUET, 2016, p. 67, tradução nossa).

A colaboração de Coquet coloca-nos no intermitente da linguagem, apresentando como ponto de vista o da fenomenologia com aplicaçóes à linguística, cuja "tarefa é colocar em evidência 'a atividade do falante', como dizem os linguistas, atividade que não pode ser dissociada da realidade do 
discurso e de suas instâncias" (COQUET, 2013, p. 1). E para quem tem por horizonte o discurso, Benveniste é reconhecidamente "o fundador da linguística do discurso" (COQUET, 2013, p. 1). Queremos nos deter nisso, para dizer que a escrita não é um signo porque, estando em condição de revezamento da fala, ela reclama viver a vida do discurso. A escrita se lança, então, à vida de traço, este em correlação à enunciação, ao dizer.

Para construirmos os resultados desta nova incursão, antes, somos convidados a notar uma liçâa dedicada à relação entre a escrita e a leitura. Esclarecendo a fronteira entre o que é "escrita" e o que é "pictografia", Benveniste traz à luz da discussão o papel da leitura. Isso porque "a pictografia pode ser compreendida, não lida, enquanto uma escrita só é escrita se pode ser lida" (BENVENISTE, 2014, p. 180, grifo do autor). A leitura surge, nesse prisma, como critério da escrita, pois "'Ler' e 'escrever' são o mesmo processo no homem; um não ocorre jamais sem o outro" (BENVENISTE, 2014, p. 180). A leitura e a escrita são, dessa forma, "duas operaçóes complementares tão estreitas e necessariamente associadas que uma é como o avesso da outra" (BENVENISTE, 2014, p. 180). Diante dessa visão da leitura como componente operacional da escrita, apresenta-se uma outra forma de significar a escrita, muito distinta dos trabalhos documentais disponíveis sobre escrita e pictografia.

Essa relação "simétrica à da fala ouvida com a fala enunciada" (BENVENISTE, 2014, p. 181) é destinada à presença do homem na linguagem, já que “'Ler' é 'ouvir'; 'escrever' é 'enunciar" (BENVENISTE, 2014, p. 181). Pela leitura do curso de Benveniste, em 1968-1969, consolidamos a originalidade de sua visão, porque sua perspectiva da escrita remonta à significação. Assim, se a língua se revela como um sistema complexo, Benveniste trata de estabelecer o lugar da escrita em relaçáo com a língua, sem abandonar o grau de complexidade presente na língua em si. E, partindo do que entendemos ser uma contestação dos territórios teóricos que concebem à escrita um lugar estático, presenciamos, nestas nobres liçôes, Benveniste abordar a escrita inserida no mundo dos homens, ou seja, na sociedade. Além de uma relação semiológica entre sistemas, que deriva a noção de autossemiotizaçáo, Benveniste vincula a escrita ao homem da fala, à vida do discurso.

Dessa maneira, o diálogo das liçôes de Benveniste, em que língua não é apenas um sistema de signos, mas, sim, que ela é $o$ sistema que interpreta os demais e engendra a possibilidade de novos sistemas, redimensiona a própria noção de língua, que "deve compreender mais noçóes do que aquelas que 
lhe foram atribuídas" (BENVENISTE, 2014, p. 182). Quando "somos levados à língua", modifica-se "a própria natureza da semiologia", pois, no nível da análise semiótica, o sistema deve ser reconhecido; enquanto, no nível da análise semântica, deve ser compreendido. Por isso, "'reconhecer' e 'compreender' dirigem-se a centros fisiológicos absolutamente diferentes" (BENVENISTE, 2014, p. 182). A semiologia não pode mais estar restrita ao signo, precisa ser da língua, elaborada no semiótico e semântico, porque, para ser interpretante, é preciso conseguir ver e refletir toda a língua.

A competência ou a capacidade de interpretância é, por isso, compreendida em seu aspecto funcional como mecanismo técnico operacional da língua. Dotada dessa capacidade de semiotizar outros sistemas, "A língua é posta na medida em que permite articular uma interpretação" (BENVENISTE, 2014, p. 190), assim, com a língua, podemos descrever tudo, inclusive a língua mesma. A escrita desempenha, aqui, um importante papel, o de viabilizar a interpretância da língua. É dizer: quem interpreta a língua? Ela mesma. Como isso é possível?

Ora, por intermédio de um sistema de signos que trabalha, engendrando a língua, semiotizando-a, a língua procede sua autossemiotização e sua própria interpretância na e pela escrita. E, se "Nenhum outro sistema dispóe de uma 'língua' na qual possa formular suas próprias interpretaçōes" (BENVENISTE, 2014, p. 190), essa propriedade singular da língua reitera, com as Últimas aulas, um limite instituído por Benveniste: tudo passa pela língua para ter sua interpretância, e a escrita passa pela língua, que passa pela escrita para ter, enfim, também sua interpretância. Esse é o laço fundamental entre a língua e a escrita. Mais uma vez a dimensão da "relação", colocandose no processo de construçáo de uma semiologia da língua.

Normand (2009a, p. 164) define que, em Semiologia da lingua, Benveniste expóe uma teoria da linguagem, "em que se resume o processo de apropriação da língua pelo sujeito, graças ao aparelho formal da enunciação" Ao acompanharmos o itinerário teórico de Benveniste, estamos situados no seu empreendimento do duplo programa da linguística, pois a linguística de Benveniste desenvolve esta especificidade da língua, a de ser investida de uma dupla significância. Essa sua disposição de trabalhar com dois mundos que se encontram na significância do semiótico e do semântico é, definitivamente, o traço marcante de Benveniste. Ademais, outra de suas marcas fundamentais é a sua capacidade de renovar as questóes, tratando-as pelos olhos da linguística geral.

Então, quando Normand (2009a) vê, em Semiologia da língua, uma 
teoria da linguagem, somos tentadas a dizer que Benveniste submete aos seus fundamentos essenciais, na elaboração das últimas aulas, um objeto como a escrita não apenas para modificá-lo, mas, uma vez tocado pela linguagem, para torná-lo outro, para agir sobre a sua integridade e integração, que, queiramos ou não, desde suas liçôes, faz parte de um sistema complexo de relaçôes de ordem semiológica e que envolve a própria interpretância da língua. Com isso, Benveniste já diz mais do que muitos disseram sobre a escrita.

As possibilidades que Benveniste abre renovam o fôlego da pesquisa linguística. Nesse novo horizonte, precisamos, ainda, pensar como essa teoria da linguagem, versada na semântica da enunciação, pode contribuir para o exame das relaçóes entre linguagem, homem, sociedade, e cultura, ambientadas na escrita. Esse arranjo investigativo possivelmente sustentará, em objetos futuros, outra face do problema do sentido.

\section{Consideraçóes finais: as liçóes renascem o problema do sentido}

A constituição das Últimas aulas, Semiologia e $A$ língua e a escrita não são apenas a representação capitular de uma obra, é um conjunto de liçôes que nos coloca em posição de retorno ao todo teórico do linguista Émile Benveniste. Isto é, suas últimas aulas despertam não só um acervo "adormecido", como lembram Jean-Claude Coquet e Irène Fenoglio, na Introdução dessa publicação; as liçôes também demonstram a intensidade da sua atuação teórico-acadêmica no período do Collège de France.

A leitura das liçóes de 1968 e 1969 permite-nos ver Benveniste reunir, em sua experiência investigativa, os argumentos para pensar no sistema da língua, na medida em que pensa em suas possíveis relaçôes. Desse ângulo, Benveniste decide apresentar uma relaçáo particular, e ela repercutirá, na sua ordem, a maneira de ver o sistema de relaçóes, pois o linguista, enfim, estreia o debate sobre o sistema da escrita. No curso dessa reflexão, a escrita surge como verdadeira revoluçáo. Isso porque ela se revela, em princípio, como ferramenta técnica às sociedades, mas, principalmente, porque ela é, no corpo linguístico, segunda fala, sistema paralelo ao sistema da língua. Uma formulação dessa envergadura, aos olhos das liçôes benvenistianas, precisa ser reconhecida pelo linguista e trabalhada pela linguística. É, então, a perspicácia semiológica de Benveniste que conduz a retirada da escrita de um lugar estático e comodamente definido em sua realidade externa 
da língua, para pensá-la como um elemento de relações com o sistema da língua.

Partindo, então, da abordagem relacional entre os sistemas da língua e da escrita, o linguista consegue conceber um novo posicionamento, para entender a dimensão do próprio sistema da língua. É desse modo que Benveniste explicita, em seu intento, que a escrita é um sistema que não ocupa a mera posição de representaçáo da língua, mas que, na verdade, uma é paralela à outra. Pelo raciocínio de Benveniste, somos convidados a notar que, submetendo a escrita à prova, é possível desdobrar sua propriedade fundamental, ela veste a própria língua, para significá-la como sistema, em um processo que esse célebre linguista determina ser a autossemiotização da língua. A argumentaçáo central de Benveniste demonstra a experiência e o testemunho do poder de interpretância da língua. Nesse enquadre, a escrita assume outro status, está inserida no aspecto semiológico da língua, na medida em que um laço une essas duas partes envolvidas.

Não menos formidável, em nosso percurso, é pensar que, à moda benvenistiana, as relaçôes estabelecidas com a língua estão ancoradas na perspectiva do semântico. O estudo do sentido da atividade linguística é, assim, uma das fortunas que herdamos do pensamento benvenistiano. Essa tessitura reticular e reflexiva de Benveniste é apresentada por Normand (2009a), por meio da percepção de que há uma "dificuldade ligada ao duplo papel da língua", a saber: "nomear o mundo (designaçáo arbitrária em relação à realidade) e dizê-lo no interior de um sistema, em relaçóes pelas quais as formas se motivam reciprocamente (significação)" (NORMAND, 2009a, p. 156-157). Essa evidência da estudiosa de Benveniste parte do texto Problemas semânticos da reconstrução (BENVENISTE I, 1954-2005).

Assim como o que Normand pontua chama atenção, de igual maneira, a percepçáo antecipada por Benveniste de que é possível abordar os problemas a partir de sua relação, já que "é pelas relações que se define uma estrutura semântica” (BENVENISTE I, 2005, p. 339). O princípio das relaçôes representa um modus operandi na linguística benvenistiana, pois "Benveniste quer dar conta [...] da mediação aos objetos operada pela língua [...] a semântica que Benveniste anuncia é uma semântica da pessoa em sua relaçáo com o mundo" (NORMAND, 2009b, p. 167-168).

$\mathrm{Na}$ operação de uma Semiologia da língua, Benveniste determina a dupla significância da língua e, dessa imagem, constrói um traço fundamental para o funcionamento da língua, porque dela decorre não só uma nova visão sobre a língua, mas também uma visão do próprio homem, que arranja e 
manuseia essa língua em busca da produção de seu sentido. Então, quando chegamos às aulas do mestre e nos deparamos com o sentido, invadindo e tensionando a reflexão de Benveniste, entendemos que ele é o seu norte, é a pedra angular de todo o seu pensamento.

Para Benveniste, há necessidade do estudo do sentido na língua como maior abertura para propor a questáo, visto que "esse estudo encontra circunstâncias objetivas mais favoráveis do que no passado" (BENVENISTE, 2014, p. 185). Isso evidencia a falibilidade da percepçáo e do estudo do sentido, porque "Sabemos que, durante muito tempo, algumas escolas linguísticas refutaram qualquer validade ou mesmo qualquer interesse aos problemas do sentido" (BENVENISTE, 2014, p. 185).

Antes de chegar ao que pretende, Benveniste reconhece que o seu lugar de fala não opera a redução ou a omissão do sentido na língua. Por isso, a problematização deve fazer entender "Como definir e onde estudar a significaçáo?” (BENVENISTE, 2014, p. 188). De fato, o linguista lembra que a significação pertence à língua, logo, "ela se distribui em cada uma das unidades da língua e se incorpora a cada uma delas, fazendo com que se tornem unidades significantes, signos" (BENVENISTE, 2014, p. 188). Outra razão para o interesse pelo estudo do sentido é "o fato de tal estudo nos fazer, no mínimo, formular novos problemas” (BENVENISTE, 2014, p. 188). Dada a importância ao estudo do sentido, é compreensível a necessidade de uma renovaçáo das percepçôes teóricas que o sustentam.

Nesse cenário, Benveniste representa não só um nome em potencial, para elaborar novas apresentaçóes, mas, pela maneira de conduzir suas discussóes, é reconhecidamente o linguista da significação, como bem o qualifica Claudine Normand em suas diversas reflexôes. Podemos dizer, entáo, que o sentido é a chave que preside a leitura do texto benvenistiano, incluindo aí o tema da escrita.

Isso em pauta, podemos afirmar: Benveniste defende que a língua inteira é "informada e articulada pela significação" (BENVENISTE, 2014, p. 188), seu funcionamento só se dá dessa maneira, ela funda a própria ideia de ser, de sociedade, "quero dizer que não podemos enfrentar uma tal representação: uma humanidade que ignoraria a linguagem e que, no entanto, seria posta na existência” (BENVENISTE, 2014, p. 188). De tudo o que, até aqui, presenciamos nas liçóes de Benveniste, chegamos ao ponto em que ele declara a nossa dependência existencial da língua, e a dependência da língua em relação à significaçáo. $\mathrm{O}$ argumento de que se vale é demonstrativo disto: "Na realidade, sem a significação, a língua não é mais 
nada, nem mesmo uma série de ruídos, pois por que o homem abriria a sua boca a não ser para formar sons que tenham um sentido?" (BENVENISTE, 2014, p. 188). A relação homem e língua fica, assim, instituída.

A atenção que Benveniste dedica, para dialogar sobre o signo saussuriano, quer resguardar que signo e sistema de signos formalizam a estrutura semiótica. Por conseguinte, "Se a língua pode ser um interpretante geral, é porque não é apenas um sistema em que manejamos signos. Trata-se do único sistema no qual podemos formar frases" (BENVENISTE, 2014, p. 191). Chegar ao nível da frase é chegar à dimensão da língua viva. Nesse nível da análise, uma nova relaçáo deve ser instituída, vinculada ao elemento do sentido, porque a frase está ligada ao discurso. Desse modo, para Benveniste, é preciso saber como o linguista pode olhar e compreender esse fato.

A liçâo consiste em articular, na escrita ou pela escrita, duas dimensões da língua: o reconhecimento do semiótico e a compreensão do semântico, eis aí outro diferencial da reflexão do linguista. Paralelamente, compreender que o trabalho fundamental de Saussure quer classificar "a língua nos sistemas, articulando-a pelo signo, Saussure - paradoxalmente - a classificou entre os sistemas não significantes, aqueles cujos elementos nada significam sozinhos." (BENVENISTE, 2014, p. 191). A partir disso, Benveniste demonstra que há um outro domínio dessa língua, "este do querer-dizer que está ligado à produção e à enunciação das frases, o semântico" (BENVENISTE, 2014, p. 191, grifo do autor). Revelam-se, assim, duas maneiras de analisar a língua, "dois mundos e duas linguísticas": o mundo da enunciação, forjado pela dupla significância da língua; a linguística no ponto em que Saussure a deixou e a linguística desenvolvida por Benveniste.

Para Benveniste, de um lado, está "o mundo das formas de oposição e de distinção, o semiótico, que se aplica a inventários fechados, e se apoia em critérios de distintividade, mais ou menos elaborados" (BENVENISTE, 2014, p. 191). De outro, o "mundo é o do sentido produzido pela enunciação: o semântico" (BENVENISTE, 2014, p. 192, grifo do autor). Em consonância com esses delineamentos, Benveniste faz questão de frisar que Saussure se ocupa da parte semiotizável da lingua, sem se ocupar da sua aplicação à língua como produção. Isso exibe as credenciais para enfrentar $o$ problema do sentido que, na realidade, é o problema da própria língua, como nos diz Benveniste.

Embora não tenha havido tempo suficiente para que Benveniste divulgasse suas consideraçóes sobre a escrita, nem mesmo recebesse a réplica de seus contemporâneos também dedicados ao tema, ele contribuiu com uma 
exposição crítica em defesa da escrita, sem tratar de tentar dizer tudo sobre ela, mas tentar nos dizer o que a escrita pode ser, se vista pelo que ela tem de particular. Em um gesto um tanto subversivo, Benveniste coloca a escrita na veia da semiologia, discussão de vanguarda e da língua. Audaciosamente, sentencia a língua a significar exatamente da mesma maneira que a escrita. Exige, ainda, que a língua semiotize a si mesma e acresce, ao conjunto argumentativo, a evidência de que a escrita é segunda fala, portanto, uma forma secundária do discurso cujo avesso funda o ato de leitura.

Poderíamos dizer que, com isso, a escrita deixa de ser um corpo estranho na esteira do debate linguístico. Contudo, devemos reconhecer que Benveniste não simplifica os fatos, ele intensifica o valor da escrita, pois, de um lado, reconhece uma relação semiológica intensa com a língua, de outro, faz a escrita ingressar na língua como forma secundária do discurso, uma forma que constrói sua própria complexidade. Nesse modo de ver, Benveniste nos convida a voltar ao problema do sentido e, por isso, voltar à língua. Ela que aparece como uma paisagem que se move, ela que é, para o linguista, o lugar de transformaçóes.

\section{Referências}

BENVENISTE, Émile. Problemas de linguística geral I. Tradução Maria da Glória Novak, Maria Luisa Neri. 5. ed. Campinas, SP: Pontes Editores, 2005.

Problemas de linguística geral II. Tradução Eduardo Guimarães [et al.]. 2. ed. Campinas, SP: Pontes Editores, 2006.

Últimas aulas no Collège de France - 1968-1969. Tradução

Daniel Costa da Silva [et.al.]. São Paulo: Editora Unesp, 2014.

COQUET, Jean-Claude. A busca do sentido: a linguagem em questão. Tradução Dilson Ferreira Cruz. São Paulo: Martins Fontes, 2013.

À propôs de l'écriture dans la phénoménologie du langage: Benveniste et Merleau-Ponty et quelques autres. In: FENOGLIO, Irène et al. Autour d'Émile Benveniste - sur l'écriture. Paris: Éditions du Seuil, 2016.

FLORES, Valdir do Nascimento. Introduçáo à teoria enunciativa de Benveniste. São Paulo: Parábola, 2013.

NORMAND, Claudine. Emile Benveniste: quelle sémantique? In: Linx. 
Du dire et du discours. Hommage à Denise Maldidier. 1996, p. 221-238.

Convite à linguística. Tradução Cristina de Campos Velho Birk [et al.]. São Paulo: Contexto, 2009a.

- Leituras de Benveniste: algumas variantes sobre um itinerário demarcado. Letras de Hoje, Porto Alegre, v. 44, n. 1, p. 12-19, jan./mar. 2009b.

ROCHA, A.W. Émile Benveniste em suas Últimas aulas no Collège de France: a escrita em questão. 2019. Tese (Doutorado em Letras) Universidade de Passo Fundo, Passo Fundo. 